Reviews

When you come across a publication that you feel our readers would find amusing, enjoyable, interesting, opportune, or even useful, let us hear about it!

Tell us, in a couple of paragraphs, what is in it and why you like it. Remember to include the title, author, publisher, place (city) of publication, and price if known.

\section{Comment on Plantation Management} review

We would like to comment briefly on R. F. Sutton's review of Plantation Management (Ontario Ministry of Natural Resources) in the October issue.

Many of his points are well taken, notably our slip on the botanical name of white spruce. In our defence it should be noted that this bulletin is one of a series; establishing a plantation is covered in "Forest Tree Planting" and management of natural woodlands in "The Farm Woodlot". The second sentence of the introduction does mention provision of a free advisory service on forestry problems.

Seen in perspective, we hoped that this bulletin would broaden the perspective of the man who inherited a plantation and give some direction to the smaller plantation owner who wanted to work out his own problems.

\section{R. M. Dixon}

Forest Management Branch

Ontario Ministry of National Resources

Ecology of Western North America. Vol. 1 (Ed. V. J. Krajina) and Vol. 2 (nos. 1 and 2) (Ed. V.J. Krajina and R.C. Brooke). Dep. Botany, University of British Columbia, Vancouver, $112 \mathrm{p}$. and 349 p., 1965 and 1969/1970.

The two volumes include a number of papers by Prof. V. Krajina and coworkers dealing with forest ecology in British Columbia. Volume 1 includes papers presented at a symposium at the Pacific Division, American Association for the Advancement of Science Meetings at the University of British Columbia in 1964. The first paper by Krajina in Volume 1 provides an introduction to the biogeoclimatic zones of British Columbia; these zones are defined by the author as "geographical segments of the earth's climate, soil and biota that are characterized by the same general macro-climate and the same zonal soil and biota". For British Columbia, Krajina has identified 11 zones which in turn are grouped into seven regions. Eight of the other papers in this volume describe in detail various aspects of several of the zones - including coastal western hemlock, coastal Douglas-fir, interior western hemlock, subalpine mountain hemlock, and the ponderosa pinebunchgrass zones. A final paper in the volume is also by Krajina and is entitled Philosophy of Ecology. This paper was presented at a University seminar in February 1965. Volume 2 contains two major papers; the first by Krajina on the ecology of forest trees in British Columbia (146 pages) and the second by Robert C. Brooke, E. B. Peterson and $V$. J. Krajina on the subalpine mountain hemlock zone in Southwestern British Columbia (203 pages).

These various paper include a wealth of information about the forests that occur in the respective zones. Much of the detail relates to the botany of the various forest types with information also presented on their dynamic interrelationships. One paper deals specifically with the initial stages of secondary succession in the coastal Douglas-fir and western hemlock zones following logging and slash burning. In Krajina's paper on the ecology of forest trees, the author discusses for each species their climatic, nutritional and light requirements, plus information on their ecological occurrence and productivity. Not only are the commercially important conifers covered, but also such species as balsam poplar, trembling aspen, mountain alder, water birch, garry oak, and arbutus.

In total these papers - and subsequent ones - by Dr Krajina and his students present much information on the autecology and synecology of British Columbia forests that is of considerable potential use to forest managers. This potential use of Krajina's system of classification has been recognized by MacMillan-Bloedel Ltd., who have just completed an operational biogeoclimatic zone classification of forest lands on Vancouver Island and the Lower Mainland coast which will be used for forest management on an ecosystem basis.

I doubt that the research information presented in the papers will be transmitted adequately without the preparation of additional articles directed more specifically to forest managers. The volumes being reviewed are lacking in photographs, employ an ecological jargon not readily understood by non-ecologists, and include very complex tables and diagrams that require detailed study if they are to be understood. I hope that Prof. Krajina will summarize and publish his work in journals that are widely read by forest managers.

J. H. Cayford
Mushrooms of North America. Orson K. Miller Jr., Chanticleer Press, E. P. Dutton \& Co., Inc., New York. 360 p. 1972. $\$ 17.95$.

A mushroom book to satisfy the needs of all possible users was the goal to which Miller aspired. $\mathrm{He}$ has approached this difficult objective. The user has a thoroughly usable book which overcomes, largely by its consistent and economical arrangement of materials, many of the difficulties of similar books. The author uses mycological terminology throughout, but usually adds explanatory terms, without breaking continuity. We are particularly indebted to Miller for his most excellent and frequently artistic colour photographs, 292 in number The specimens were well-chosen and are portrayed to illustrate both pertinent morphologic characteristics and habitat settings. The effect is often pleasing, even when certain mushrooms do headstands in order to illustrate important features.

The casual observer with one or two older mushroom books will despair as he finds many familiar species renamed, but he will meet with the same problem in most contemporary mushroom books. More important, the beginner must not abandon the book if he is unable to determine an apparently abundant specimen. It may not be there. A book several times 360 pages would be required to do justice to the species occurring within the geographic area from which the author chose his examples, roughly the continental United States and Canada. The 422 species described are but a sample of the actual mushrooms of North America.

As with any such key, and this book is basically a key, the success of the collector will increase as he begins to interpret his observations from the author's viewpoint. He will possibly become dispirited when his specimen does not correspond with the description in all respects. More discouraging still, he will sometimes be constrained to follow a route through the key that contradicts some apparently indisputable characteristic of his specimen, before finding the route thats leads to a logical conclusion. He may also come to a dead halt in a number of instances as the author assumes that the serious mushroom collector will have access to a microscope. A second book may be of help, but all such have their limitations. The mushroom is a most variable organism at the best of times. This alone has limited the followers of the art of mushroom identification to those with considerable patience and interest and to those who plan to devour their collections. A good guess may not be enough for collectors in the latter category.

The book is well-printed and relatively durable, but would not fare well if taken into the field. The mushroom must be brought to the book 
rather than the reverse. The short section of mushroom recipes will prove a matter of individual taste, but one must marvel at the imagination of the author when he conjured-up "the mycological martini" and "mushroomers delight". Then again, one should not disdain a mixture of Marasmius oreades, chocolate drops, macaroon crumbs and maraschino cherries until one has actually tried "Marasmius cookies".

This book should be a welcome addition to the shelf of anyone interested in the topic of mushroom collecting, and could form an especially good entry for the beginner into this art.

\section{E. Dorworth}

Canada, Science, and International Affairs. Science Council of Canada, Report No. 20. Ottawa. 66 p. $\$ 1.25$.

Science Council is exploring new territory in this analysis of the interface between scientific affairs and international politics. The Report is in three parts: $1 /$ Concepts and Facts, 2/ Goals and Criteria, and 3/ Methods and Mechanisms. It is frankly aimed at policy developments for a change in attitudes and a relaxation of barriers. By recognizing the possibilities for conflict as well as the opportunities for cooperation, better policies may be evolved.

Canadian scientists who maintain their individual contacts in the "international community", who share in the activities of international organizations, who use science to maintain political lines of communication, and who assist in scientific contributions to developing countries, may appreciate efforts to integrate Canadian science policy considerations with international affairs. Report No. 20 suggests that Canada must develop the mechanisms necessary to obtain an over-view of current participation in international scientific affairs, to develop a basis for selecting those domains of science in which Canada should participate internationally, and through these make science an instrument for foreign policy.

Surely, Canada as a forest nation has much to contribute internationally through forest science. In the international field there is clear constitutional authority for the Canadian Forestry Service to represent Canada. As foresters and forest scientists we should study the implications of this report and do our best to ensure that Canada's participation in international affairs is in harmony with well defined goals for Canadian Forestry. Obviously, we have a long way to travel before we have widely agreed goals for Canadian forestry and forest science. Report No. 20 adds an important dimension by reminding us that science can and in some situations must contribute in international affairs.

J. Harry G. Smith
Education and Jobs. A. D. Boyd and A.

C. Gross. Science Council of Canada, Special Study No. 28. Ottawa. 139 p. $\$ 2.25$.

The reasons leading to initiation of this study were and are compelling. Many Canadians are worried about the labour market for graduates in science, underemployment of graduates, poor matches of supply with demand, and lack of satisfying career opportunities. There is a growing belief that things must change. University enrolments have fallen off or failed to grow at rates expected from projections of population increase and per capita incomes. Financing of research in Universities has become much more difficult in recent years. Clearly the post-Sputnik enthusiasm for education and research has diminished and $\mathrm{Ca}$ nadian taxpayers are looking for ways in which to reduce their burden. Unrest in Universities has led in some cases to damaging publicity. Although the need for science graduates may compare favourably with those from other fields there still is a concern to know whether or not the kinds of education provided are adequate within science faculties.

Special Study No. 28 undertook a primary survey of Canadian Science (Honour) graduates in chemistry or physics in the classes of 1954, 1959. and 1964. By analysis of these graduates and by comparison with results from other areas the rating in regard to education, employment, and utilization patterns was highly satisfactory. However, analysis of the replies from the graduates brought out some problems. The authors tended to accept these problems at their face value and to conclude that the need for restructuring of science curricula was adequately demonstrated. They deplored the rigid nature of science programs. However forestry, for instance, has long since moved away from the rigid kinds of programs they condemned, and I have the impression that their conclusions were not strongly supported. They confused concentration with specialization and tended to accept without serious question all of the arguments raised on behalf of a broad, general education.

Their conclusion merits repetition here, in modified form. Disciplined training, continued education, research, and pursuit of truth for the sake of truth, remain at the heart of each science graduate's professional development. "But the extent to which those educated in science can assist us in solving the highly complex problems of a scientific-technological civilization - to that extent they will be accorded esteem by others and achieve self-esteem."

This study has defined some important questions but should be followed by others which concern themselves with the full range of graduates in science. Continuing study is needed and forestry faculties in Canada should evaluate their programs in depth again soon to update and improve upon the 1971 Garratt survey of Forestry Education in Canada. We should know much more about career patterns of Canadian educated foresters and forest scientists in order to improve the match between education and jobs and to increase the satisfactions enjoyed in all aspects of our work environments.

J. Harry G. Smith

Recycling Treated Municipal Wastewater and Sludge Through Forest and Cropland. William E. Sopper and Louis T. Kardos (Eds.). Pennsylvania State University Press, University Park and London. 479 p. 1973. $\$ 16.50$.

The book, which constitutes the proceedings of a 1972 Symposium, covers the alternative to surface water discharge, namely, recycling on land. This disposal method requires both forestry and agricultural contributions to the problem solution as well as sanitary engineering technology. The book is organized into ten chapters and contains in addition to the papers presented at the Symposium a summary of the ensuing discussion and a list of literature references for each paper.

The first six chapters could have been referred to as "Part One: The Theoretical Background". Here the reader is introduced to the Living Filter Concept through presentations under the following headings: "Treated Municipal Wastewater - What is It?; "Fundamental Functions of the Soil and its Associated Biosphere"; "Wastewater Quality Changes During Recycling"; "Soil Responses"; "Vegetation Responses"; and "Other Ecosystem Responses'.

The advantages in land recycling of wastewater, as well as some of the problems it might provoke, are well presented and documented by experimental results and analytical data. This part of the book forms an excellent handbook for the waste treatment specialist seeking information outside his own area.

To the forester, the amounts of wastewater and its fertilizer quality is intriguing. One might expect as much as 100 gallons of wastewater per day per urbanite, containing about one-half pound of suspended dry matter per person. This amounts to 36.5 million gallons (165.9 million litres) of water and 90 tons ( 82 metric tons) of sludge per 1,000 inhabitants per year.

The book is relevant to the forester because it deals directly and indirectly with tree growth, soils, groundwater, precipitation, and fertilization. Increased wood production has been demonstrated after two-inches-perweek (5 cm/week) application of 
wastewater over 52 weeks undertaken in forest plantations. The 104 inches $(264 \mathrm{~cm})$ of irrigation wastewater used had a fertilizer value equivalent to $2,000 \mathrm{lb}$ of a $10-10-11$ fertilizer per acre $(2,240 \mathrm{~kg} / \mathrm{ha})$.

The final four chapters could fall naturally in "Part Two: Application of the Living Filter Concept". Here we learn about the parameters applied, in "System Design, Operation and Economics" and are provided with "Examples of Operating and Proposed Systems", as well as a review of "Present Status of Guidelines for Land Disposal of Wastewater", and a view of "Research Needs", all chapter titles.

Of particular interest to me was the information given about operating systems, which demonstrates the adaptability of wastewater irrigation systems to small as well as large communities and to special localities such as parks, ocean resorts, and fire-exposed communities in chaparral brush country. The planned utilization of the wastewater resource for rehabilitation of stripmined and eroded areas, for groundwater conservation, improved agricultural and forestry production, for development of greenbelt areas, and cooling of electric power generating plants all adds up to a fascinating look into the not too distant future. Total environmental management appears to be a necessity for future generations of mankind. This book reveals steps taken toward this achievement of particular interest to foresters and agriculturalists - the "land managers" - and deserves a wide distribution.

\section{E. Jorgensen}

Essays on Aspects of Resource Policy. Science Council of Canada, Report No. 27. Ottawa. 113 p. $\$ 2.50$.

This booklet consists of four separate essays prepared as background material for Science Council Report No. 19 Natural Resource Policy Issues in Canada. Each essay is an independent, self-contained contribution.

Science expenditures and the contributions of the resource industries to the Canadian economy / Dr W. D. Bennett. A discussion of the inter-relationships of the resource industries with the national economy based on the inputoutput tables published by Statistics Canada. A useful analysis for those working on a national level.

The systems approach to resource allocation Dr A. D. Chambers. Dr Chambers is Assistant Professor of Forestry at UBC. This second essay is a description of systems analysis and simulation modelling, including an example. It is a good reference for those working in these fields.

Jurisdictional problems in natural resource management in Canada/ $\mathrm{Dr}$ A. R. Thompson and H. R. Eddy. As the table states, this is an analysis of jurisdictional problems in resource management, but it also includes specific suggestions for improved laws. This is excellent background material on the subject.

Resources: implications of ownership / Dr. A. J. Cordell. A discussion of the why and wherefore of foreign development of Canadian resources. The examples quoted are mainly from the mining sector but the principles apply to forestry as well.

In total - a useful reference book.

E. Bonner

Report of the Director-General of Forests for the Year Ended 31 March 1973 Government Printer, Wellington, New Zealand. $45 \phi$.

This annual report of the New Zealand Forest Service provides an excellent overview of its current activities. Subjects reviewed include production forestry, production, consumption and trade, research and development, and environmental forestry. Additionally, 14 tabular appendices provide information on forest area, silviculture and management, timber removal, production of forest products, and external trade.

The opening section of the report is devoted to a general discussion of New Zealand forestry and forest policy Some $24 \%$ of the land is under forest, but in the view of the Forest Service this is insufficient to satisfy the basic human social, economic, recreational, and spiritual needs. The report notes, however, that per capita, New Zealand probably has a larger area of reserved forest than any other developed country. But clearing of forests for agriculture has led to much soil erosion especially in steep hilly and mountainous terrain and to the creation of hundreds of thousands of areas of marginal or unprofitable farm land. In both situations there is a compelling need to bring the land into production. And still the forest industry is encroaching into remaining native forests, which following cutting are reverting to a second growth of scrub hardwoods.

The report discusses the current controversy between the Forest Service and various environmental groups and notes that the latter abhor introduced pines and are opposed to further planting of exotics. An excellent argument is advanced with respect to the need to plant exotics such as radiata pine and Douglas-fir for wood products, and the report also stresses the importance of these production forests for certain environmental values such as perpetual renewability, susceptibility to recycling, and biodegradability. Canadian forest managers confronted with similar environmental controversies would be well advised to read carefully the introductory portion of this report.
The Environmental Crisis. Harold W Helfrich Jr. (Ed.), New Haven and London, Yale University Press. 187 p. 1972. \$1.95.

This compendium of 12 lectures, delivered during 1968-69 at the Yale University School of Forestry, presents both facts and a philosophy which might be essential for man's survival.

In his introduction, François Mergen states that the Yale School of Forestry, having solved many forestry problems since it was founded in 1900, must now train experts able to deal with problems of the total environment.

L. C. Cole, Professor of Ecology at Cornell University leads off with the basic problem under the title "Playing Russian Roulette with Biogeochemical Cycles". He recalls how agricultural practices, and the removal of forests from hillsides, has caused floods and erosion. He emphasizes the correlation of pollution with urbanization. His apt quotation of Samuel Taylor Coleridge is particularly interesting when the date (1800 A.D.) is considered:

The River Rhine, is well known,

Doth wash your city of Cologne:

But tell me, Nymphs, what power divine

Shall henceforth wash the River Rhine?

Cole's correlations of plant activities including the role of forest stands and the composition of the atmosphere are most revealing.

Ian L. McHarg, Professor and Chairman of the Department of Landscape Architecture and Regional Planning at the University of Pennsylvania approaches the problem philosophically and aesthetically. His historical picture is concerned with the disappearance of green belts under the hand of the developer, loss of land carried away by water, the quality of water, etc. $\mathrm{McHarg}$ is primarily concerned with man's drastic imprint on nature. Man's turn to ecologists for his understanding of the world is his prescription for a better life.

David Gates, Director of the Missouri Botanical Garden, with the rare distinction of being both physicist and botanist, discusses "Weather Modification in the Service of Mankind: Promise or Peril?" He believes that the earth's ecosystem is a giant thermodynamic machine driven by sunlight slowly evolving over a billion years or so. While advocating man's exploitation of the earth and intelligent management of the environment, Gates asks "But will he?"

Paul Erlich, Professor of Biology at Stanford University, had for his topic "Famine 1975: Fact or Fallacy?" He presents an interesting discussion on demography, showing how lifespan must be considered along with birth rate.

William A. Niering, Director of the Connecticut Arboretum and Professor 
of Botany at Connecticut College on one of his favourite topics: "The Dilemma of the Coastal Wetlands: Conflict of Local, National, and World Priorities", states that of the original 127 million acres ( 51 million ha) of wetlands in the United States only about $60 \%$ remain today. A great conflict has developed over the years between man's utilization of this land and the natural ecology.

James G. Horsfall, Director of the Connecticut Agricultural Experiment Station, considers "The Green Revolution: Agriculture in the Face of the Population Explosion" points out that in the United States one hundred years ago $95 \%$ of the population worked the land whereas today less than $5 \%$ of the total population produces food. Horsfall substantiates the reasons for this change with figures for crop yields, and he suggests ways of feeding the growing population.

Other papers, though of less direct interest to foresters, are all relevant to environmental quality, a subject of vital concern to everyone.

D. A. Fraser

\section{the spot}

\section{seen 'round} the world

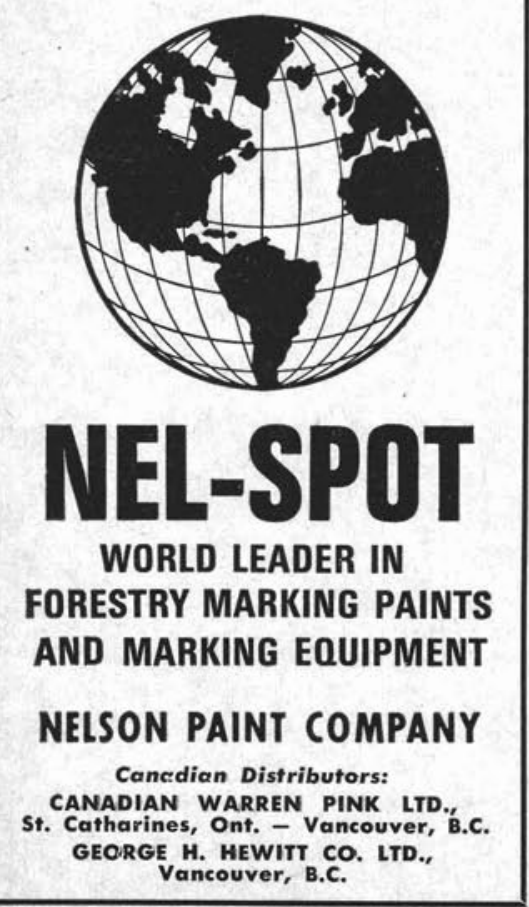

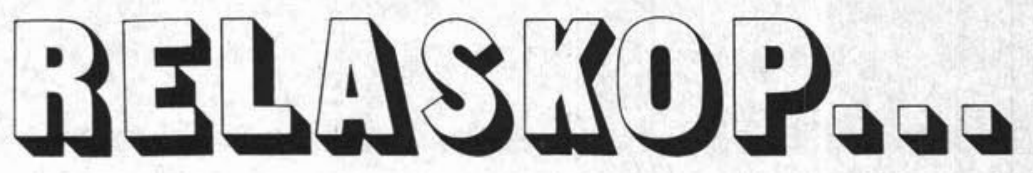
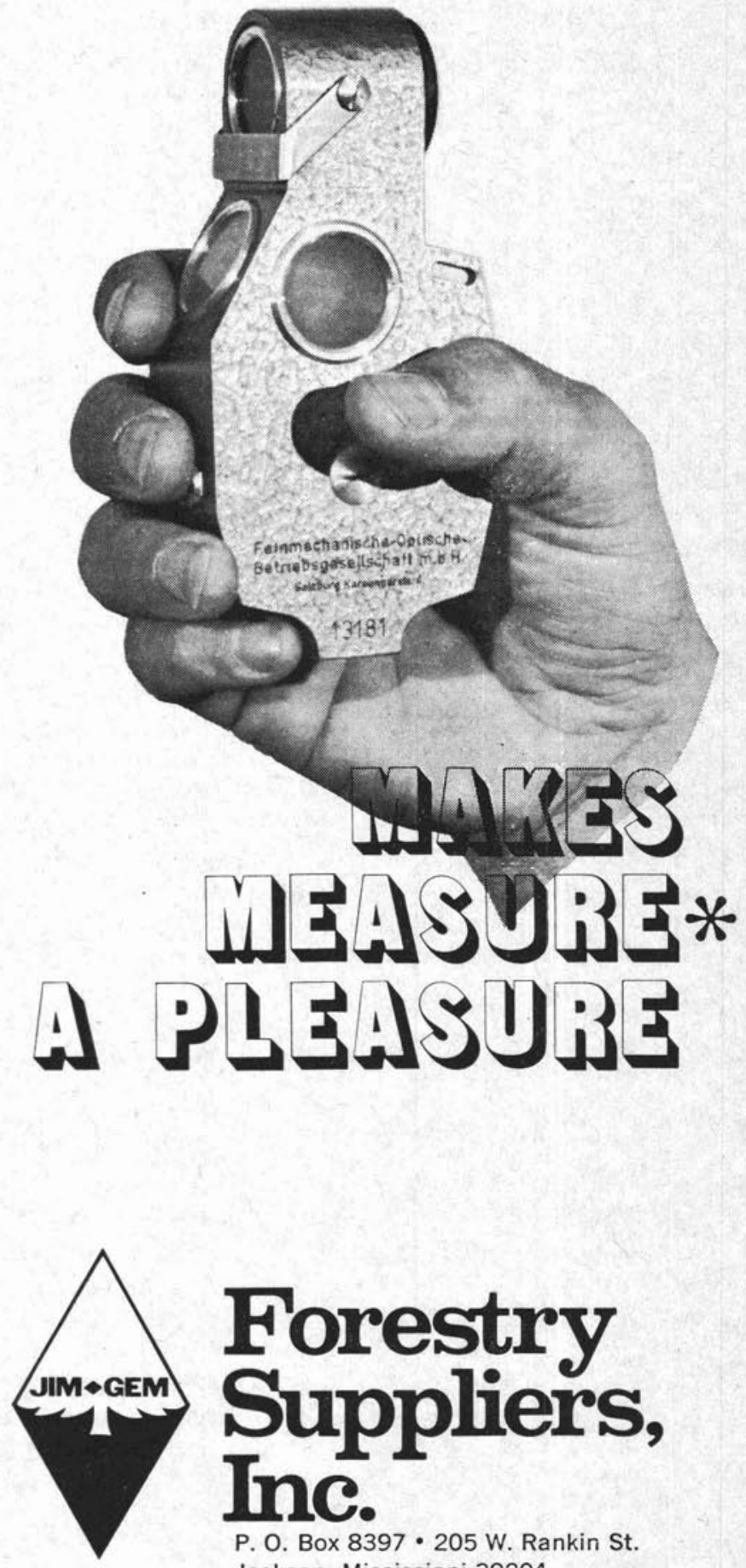

P. O. Box $8397 \cdot 205$ W. Rankin St. Jackson, Mississippi 39204

*measure tree heights

*measure tree diameters

* measure tree distance

* measure basal area 